\title{
Sedimentary deposition of Bozeş Formation (Apuseni Mts., Romania) - detrital zircon dating and micropaleontological ages
}

\author{
Ramona BĂLC ${ }^{1 *}$ \& Luminița ZAHARIA ${ }^{2}$ \\ ${ }^{1}$ Babeş-Bolyai University, Faculty of Environmental Science and Engineering, Fântânele 30, \\ 400294 Cluj-Napoca, Romania \\ ${ }^{2}$ Babeş-Bolyai University, Museum of Mineralogy and Department of Geology, Kogălniceanu 1, \\ 400084 Cluj-Napoca, Romania
}

Received: November 2013; accepted January 2014

Available online 17 January 2014

DOI: http://dx.doi.org/10.5038/1937-8602.58.2.4

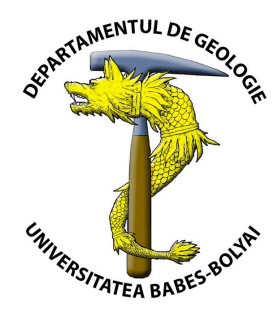

\begin{abstract}
In order to establish the age of the Bozeş Formation, which crops out in the SE Apuseni Mts., calcareous nannofossils investigations and U-Pb detrital zircon dating were performed in the Stăuinii Valley section. The results were correlated, and further compared with previous fossil age data. The U-Pb detrital zircon age spectrum reveals a consistent Late Cretaceous grain population, which yielded an age of $83 \mathrm{Ma}$ (concordia age of $82.87 \pm 0.59 \mathrm{Ma}$ ), interpreted as the maximum deposition age, thus, marking the Early Campanian as the initiation of sediment deposition. Based on the presence of some important taxa in the calcareous nannofossil assemblage, the age of studied section was assigned to Late Santonian? - late Late Campanian. The Late Santonian age is presumed by the presence of curved Lucianorhabdus cauyeuxii, reworked from older deposits. The Campanian stage is confirmed by the presence of Broinsonia parca parca, Broinsonia parca constricta and rare specimens of Ceratolithoides aculeus and Uniplanarius sissinghii. Both Reinhardtites anthophorus and Eiffelithus eximius indicate that the upper part of the Stăuinii section is ending in $\mathrm{CC} 22 / \mathrm{UC}_{1}{ }_{\mathrm{d}}^{\mathrm{TP}}-\mathrm{UC} 15_{\mathrm{e}}^{\mathrm{TP}}$ Subzones, thus in late Late Campanian. First occurrence (FO) of Eiffellithus parallelus points to the same age. The calcareous nannofossil assemblages do not sustain the presence of the Lower Maastrichtian deposits in the Stăuinii Valley, as mentioned by few previous studies based on Pachydiscus neubergicus.
\end{abstract}

Keywords: calcareous nannofossils, Campanian, bioevent, marker species, siliciclastic rocks

\section{INTRODUCTION}

Sedimentary rocks record data about the composition of continental crust, the changes of climate, the variation of the atmosphere and hydrosphere compositions, as well as the evolution of life during Earth History (Rasmussen, 2005 and references therein). Dating a sedimentary rock means mainly constraining its age in terms of sediment deposition and, in some cases, of the subsequent processes such as diagenesis. In most situations, if present, fossils, i.e. the remains of past organisms provide the easiest way to establish the depositional age of sediments. However, there are cases when sedimentary successions are missing a proper fossil record, or the low abundances or diversity are not suitable for stratigraphic correlation. Alternatively, some indirect, radiometric techniques are also widely involved, as dating contemporaneous volcanic rocks or detrital minerals within the sediment. These, too, cannot be always applied, as many basins lack volcanic rocks, while detrital minerals yields only maximum ages, thus the ages when they formed in their originally magmatic rocks.

The Upper Cretaceous Bozeş Formation from the Apuseni Mountains is widely considered as Santonian - Early Maastrichtian in age, as constrained by several macro- and microfauna-based studies (Macovei and Atanasiu, 1934; Dimian and Popa-Dimian, 1964; Tomescu et al., 1969; Marincaş and Mânecan, 1971; Marincaş, 1973). However, different studies performed even on the same section resulted in different age limits. Placed in the eastern part of
Bozeş Formation, the Stăuinii Valley section is such a controversial area regarding the depositional age of sediments, the limits varying from Late Santonian to Early Maastrichtian, depending on the described fossil assemblages and different authors.

For the first time in case of the Bozeş Formation, a radiometric method is used, as U-Pb dating of detrital zircon, and combined with a new complementary calcareous nannofossils study, in order to correlate the results and to constrain better the age of sediment deposition.

\section{GEOLOGICAL SETTING}

Although the Apuseni Mountains represent an isolated unit between the Pannonian and the Transylvanian basins, tectonically, they are part of the Alpine-Carpathians mountain belt, being the result of complex plate movements during Mesozoic to Cenozoic. Specifically, the Apuseni Mts. resulted from the collision of the Tisia and Dacia microplates during Cretaceous times (Csontos, 1995), the suture between these two being preserved in the south and southeastern part of the mountains. Several tectonic units are building up the Apuseni Mts., namely Bihor Unit, Apusenides and Western Transylvanides. These units are separated and sub-divided according to the age of the tectonic phases and their corresponding nappe emplacement (Ianovici et al., 1976; Săndulescu, 1984; Balintoni, 1997). In the southern Apuseni Mts, only units belonging to Transylvanides and Apusenides occur (Fig. 1a). 
Cropping out in the southeastern part of the Apuseni Mts. (Fig. 1a), the Bozeş Formation represents the uppermost unit among the Western Transylvanides (Ghiţulescu and Socolescu, 1941; Bleahu et al., 1981), although much recently, the Bozeş Formation was tectonically affiliated to Southern Carpathians (Balintoni, 2003), both ideas being in use. The Bozeş Formation consists of $c a$. $3000 \mathrm{~m}$-thick, turbidite-type sediments as grey sandstones and silty marls, with fine-grained conglomeratic levels in the upper part (Dimian and Popa-Dimian, 1964). Based on macroand microfauna, the age of the formation was considered Santonian - Campanian - Early Maastrichtian (Macovei and Atanasiu, 1934; Dimian and Popa-Dimian, 1964; Tomescu et al., 1969; Marincaş and Mânecan, 1971; Marincaş, 1973; Bălc et al., 2007, 2012).

\section{PREVIOUS MICROPALEONTOLOGICALAGE DATA ON STĂUINII VALLEY}

At the beginning of the 20th century, Bozeş sedimentary rocks cropping out in the Stăuinii Valley section were considered by Palfy (1903, in Dimian and Popa-Dimian, 1964) as Campanian in age, due to a macrofauna occurring on various levels, with Inoceramus, Actaeonella, Cerithium and Sabal major. Nopcsa (1905, in Macovei and Atanasiu, 1943) reported the presence of Pachydiscus neubergicus and P. colligatus, based on which Macovei and Atanasiu (1934) assigned an Early Maastrichtian age for parts of the Stăuinii Valley deposits. As a result of a more detailed study on foraminifera assemblages performed along the valley, Dimian and Popa-Dimian (1964) assigned a Late Santonian - Campanian age for the sediments, the base of the section being represented by the upstream deposits, while downwards they become stratigraphically younger. The same authors also described an ammonite fauna, including $P$. colligatus but without $P$. neubergicus. Tomescu et al. (1969) reported a diverse fauna in Stăuinii Valley, including inoceramids and ammonites, e.g. Inoceramus balticus, I. regularis, Hoplitoplacenticeras vari, Pachydiscus neubergicus and $P$. colligatus, all occurring at the same level. The authors mentioned the above-described fauna as being specific for the Late Campanian of Western Europe, but with $P$. neubergicus cited from Lower Maastrichtian deposits too. Thus, the Stăuinii deposits were considered by the previous authors as Campanian-Early Maastrichtian in age.

\section{CALCAREOUS NANNOFOSSIL ANALYSES}

Due to their abundance, rapid evolution and cosmopolitan character, calcareous nannofossils represent a useful tool in biostratigraphical studies. They are widely used since the 1950s, and all the data obtained were involved in building the biostratigraphic zonation schemes covering the range of calcareous nannofossils (Martini, 1971; Sissingh, 1977; Perch-Nielsen, 1985; Okada and Bukry, 1980; Bown et al., 1998; Burnett, 1998).

\section{Materials and methods}

A number of 200 clay samples has been collected from Stăuinii Valley in order to establish the age of the deposits based on calcareous nannofossil assemblages. The smear slides have been processed using the standard method (Bown and Young, 1998). For calcareous nannofossils analyses at least 300 specimens have been identified in each sample and another 1000 FOV (fields of view) have been browsed in order to identify the rare specimens using a Zeiss Axiolab A microscope at 1000x magnification. The pictures of calcareous nannofossils have been captured with an AxioCamERc5s digital camera (Fig. 2). All the identified species
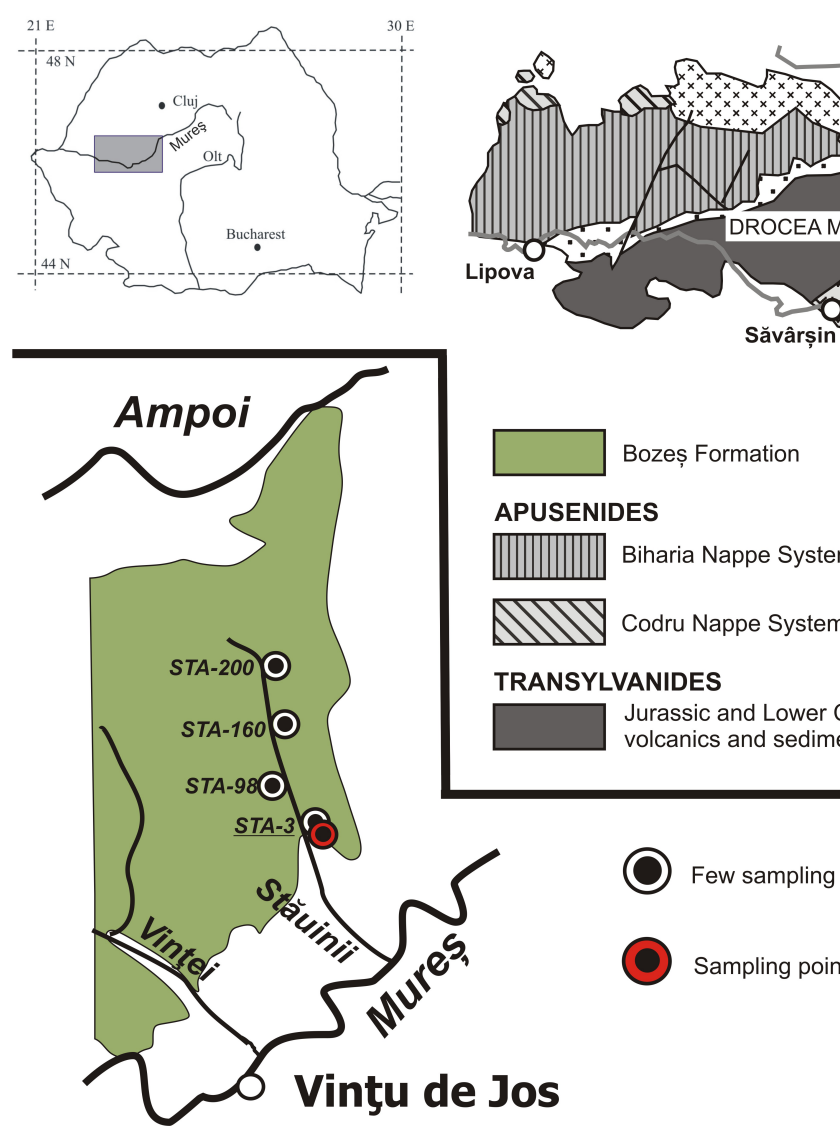

Bozeș Formation

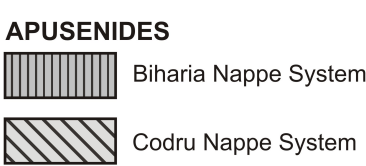

TRANSYLVANIDES

Jurassic and Lower Cretaceous volcanics and sediments

Fig. 1. a) Sketch of the main tectonic units in the Southern Apuseni Mts, showing the location of the Bozeş Formation (simplified after Balintoni et al., 2009) and of the studied area (red square); b) Enlarged map of the western part of the Bozeş Formation, with location of Stăuinii valley and of some sampling points (modified after Lupu et al., 1967). 

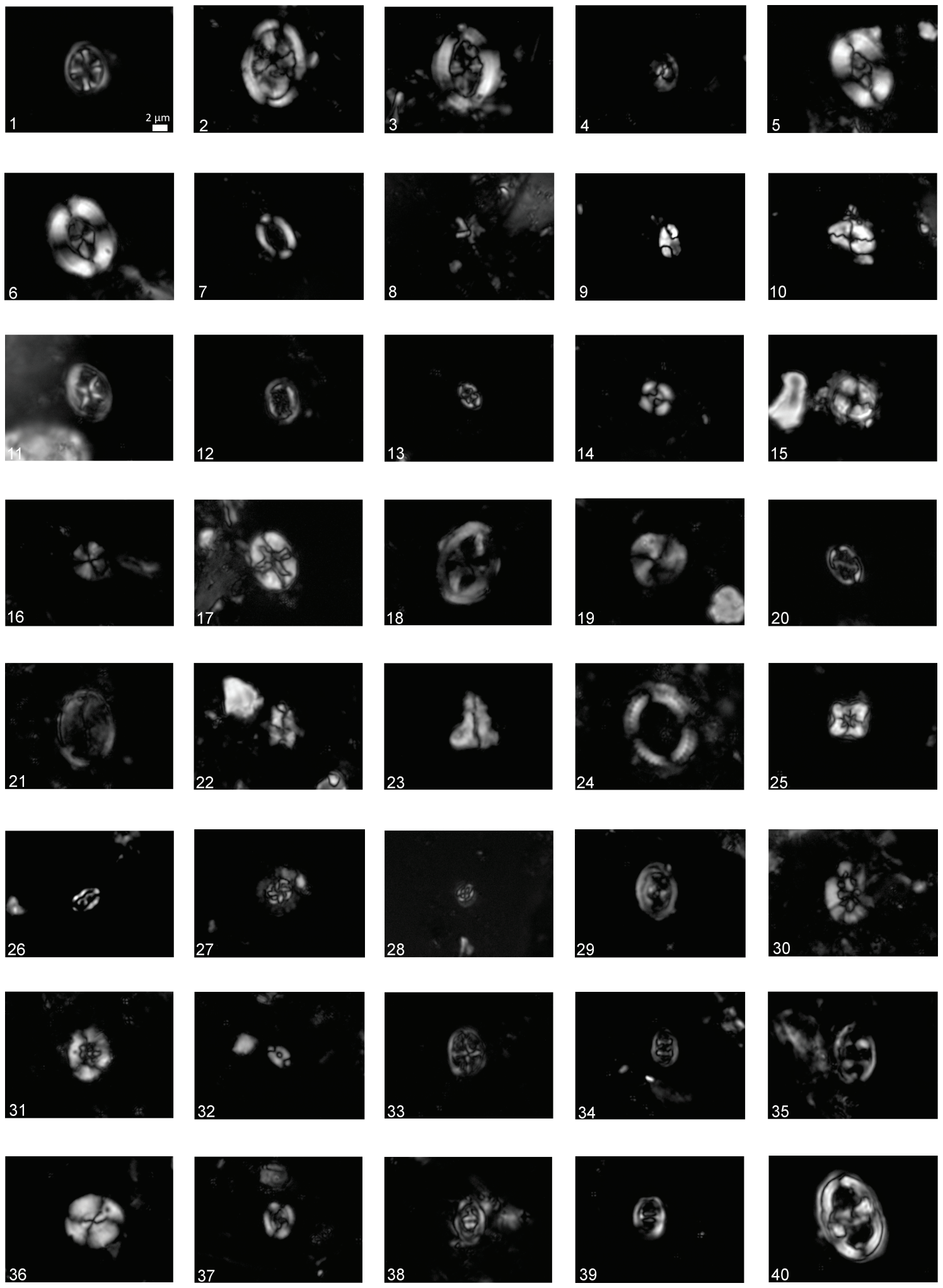

Fig. 2. Calcareous nannofossils from Stauini Valley section. The photographs were taken under cross-polarized light. 1) Ahmuellerella octoradiataSamples 45; 2) Arkhangelskiella cymbiformis - Sample 177; 3) Arkhangelskiella maastrichtiana - Samples 168; 4) Biscutum constans - Sample 167; 5) Broinsonia parca constricta - Sample 172; 6) Broinsonia parca parca - Sample 170; 7) Broinsonia parca expansa - Sample 44; 8) Bukryaster hayi Sample 171; 9) Calculites obscurus - Sample 25; 10) Calculites ovalis - Sample 167; 11) Chiastozygus amphipons - Sample 174; 12) Cribrosphaerella ehrenbergii - Sample 45; 13) Corollithion madagaskariensis - Sample 140; 14) Cyclagelosphaera rotaclypeata - Sample 175; 15) Cylindralithus sculptus - Sample 168; 16) Discorhabdus ignotus - Sample 139; 17) Eiffelithus eximius - Sample 176; 18) Gartnerago segmentatum - Sample 139; 19) Haquis circumradiatus - Sample 137; 20) Helicolithus trabeculatus - Sample 143; 21) Kamptnerius magnificus - Sample 139; 22) Lithastrinus grillii - Sample 174; 23) Lucianorhabdus maleformis - Sample 166; 24) Manivitella pemmatoidea - Sample 132; 25) Micula staurophora - Sample 143; 26) Okkolithus australis - Sample 26; 27) Prediscosphaera cretacea - Sample 174; 28) Prediscosphaera stoveri - Sample 44; 29) Reinhardtites anthophorus - Sample 139; 30) Retecapsa angustiforata - Sample 177; 31) Retecapsa crenulata - Sample 45; 32) Russelia bukryi - Sample 139; 33) Staurolithites imbricatus Sample 139; 34) Tranolithus minimus - Sample 168; 35) Tranolithus orionatus - Sample 166; 36) Watznaueria barnesiae - Sample 167; 37) Watznaueria quadriradiata - Sample 136; 38) Zeugrhabdotus bicrescenticus - Sample 169; 39) Zeugrhabdotus diplogrammus - Sample 168; 40) Zeugrhabdotus embergeri-Sample 164 
are mentioned in Appendix 1. Relative abundance of each species and Shannon Index were calculated according to Murray (2006). For age determination biozonation schemes of Sissingh (1977), Perch-Nielsen (1985) and Burnett (1998) have been used.

\section{Calcareous nannofossil assemblage results}

The calcareous nannofossil assemblages contain 101 species. The preservation is poor to moderate. The diversity slightly increases toward the top of the section. A positive correlation between abundance and diversity can be recognized. The most abundant species is Watznaueria barnesiae (31.7$61.6 \%)$, followed by Prediscosphaera cretacea $(3.4 \%-13 \%)$, Micula staurophora (0.6\%-11\%), Retecapsa crenulata $(1.7 \%$ $11 \%)$, Eiffelithus eximius (0.7\%-8.9\%), Tranolithus orionatus (1.7\%- 7\%) and Cribrosphaerella ehrenbergii (1.4\%-5.8\%). Some important species are continuously present in the studied samples: Broinsonia parca constricta, Broinsonia parca parca, Reinhardtites anthophorus, Lithastrinus grillii together with rare specimens of Lucianorhabdus cayeuxii. The tethyan species are very rare: Uniplanarius sissinghii - 2 specimens; Ceratolithoides aculeus -7 specimens and Uniplanarius gothicus - 6 specimens. Cold-water taxa are present in the assemblage, Biscutum constans being the most abundant (its abundance increases toward the top of the section, where it reaches 5\%) together with Ahmuellerella octoradiata, Gartnerago segmentatum, Zeugrhabdotus erectus, Prediscosphaera stoveri, etc.

\section{Age of sedimentary deposits}

A detailed biozonation for the entire section is difficult to draw due to the bad preservation and absence of marker species. It is possible that the studied section begins with the Late Santonian due to the presence in some samples of curved Lucianorhabdus cayeuxii, a marker species for the uppermost Santonian - lowermost Campanian (Wagreich, 1992).

The presence in the analyzed samples of Campanian taxa such as Broinsonia parca parca, Broinsonia parca constricta, Ceratolithoides aculeus, Uniplanarius sissinghii, although some of them in a very low number, indicates a Campanian age of the deposits. Only three Campanian bioevents can be outlined: FO of Reinhardites levis, FO of Prediscosphaera stoveri and FO of Eiffelithus parallelus. The FO of $R$. levis is located in UC14 Zone (upper Lower Campanian) in the Tethyan Realm and in UC15 Zone (lower Upper Campanian) in the Boreal Realm (Burnett, 1998). P. stoveri is mentioned from both northern and southern hemispheres. In the North Sea its FO is placed at the base of UC15 ${ }_{\mathrm{d}}^{\mathrm{BP}}$ (lower Upper Campanian) (Burnett, 1998) and in Biscutum coronum Zone (upper Upper Campanian) in the Southern Hemisphere (Watkins et al., 1996). E. parallelus is used as a marker species for $\mathrm{UC}_{1} 5_{\mathrm{d}}^{\mathrm{TP}}-\mathrm{UC} 15_{\mathrm{e}}{ }^{\mathrm{TP}}$ (lower Upper Campanian to upper Upper Campanian), marking the top of $\mathrm{UC} 5_{\mathrm{d}}{ }_{\mathrm{TP}}$ and the base of $\mathrm{UC} 15_{\mathrm{e}}^{\mathrm{TP}}$, respectively (Burnett, 1998).

In the studied deposits, E. parallelus has been identified in the samples collected from the upper part of the section, together with $E$. eximius and $R$. anthophorus. The last two mentioned species have their LO at the top of $\mathrm{UC}_{15}{ }_{\mathrm{e}}^{\mathrm{TP}}$ (upper Upper Campanian). Thus, the upper part of the Stăuinii section falls in the UC15 ${ }_{d}^{\text {TP }}-\mathrm{UC} 15_{\mathrm{e}}^{\text {TP }}$ Subzones (Burnett, 1998), approximately equivalent to CC22 biozone (Sissingh, 1977; Perch-Nielsen, 1985). Therefore, the age of the top deposits of the Stăuinii Valley is Late Campanian, not reaching the Campanian/Maastrichtian boundary.

\section{U-PB DETRITAL ZIRCON AGE ANALYSES}

Due to its physical and chemical stability, detrital zircon is widespread in almost all siliciclastic rock types; therefore it is very useful in isotopic age investigation. The U-Pb dating of detrital zircon produces a spectrum of age populations, which can be used to constrain information on the age of the sediment sources, the orogenic history and paleogeography of ancient hinterlands, or even to establish the maximum depositional age of the sedimentary rock (e.g. Maas and McCulloch, 1991; Nelson, 2001; Avigad et al., 2003; Fedo et al., 2003).

\section{Material and analytical methods}

The sandstone selected for zircon $\mathrm{U} / \mathrm{Pb}$ geochronological analysis (STA-3) was collected from the downvalley of the Stăuinii Stream (Fig. 1b). The sampling point is located in the uppermost part of the section, of Late Campanian age, as constrained by the calcareous nannofossil results, from above and below the sandstone level.

About $2 \mathrm{~kg}$ of fresh rock were crushed, sieved and treated with heavy liquid (diiodomethane) for separating the heavy mineral fraction. Zircon grains were hand-picked under a binocular microscope, all grain size and morphology being selected. The grains were mounted in epoxy and polished to expose their internal structure, which was revealed by cathodoluminiscence (CL) imaging using a Zeiss EVO50 SEM coupled to a $\mathrm{CL}$ detector system. $\mathrm{U}, \mathrm{Th}$, and $\mathrm{Pb}$ isotopes were measured for zircon grains by Laser Ablation with Inductively Coupled Plasma Mass Spectrometry (LA-ICP-MS) techniques using a Thermo-Scientific Element 2 XR sector field ICPMS coupled to a New Wave UP-193 Excimer Laser System. The analysis used laser spot-sizes between 20 and $35 \mu \mathrm{m}$ and consisted of $15 \mathrm{~s}$ of background acquisition followed by $25 \mathrm{~s}$ of data acquisition. A common- $\mathrm{Pb}$ correction based on the interference- and background-corrected $204 \mathrm{~Pb}$ signal and a model $\mathrm{Pb}$ composition (Stacey and Kramers, 1975) was carried out if necessary. The raw data were corrected for background signal, common- $\mathrm{Pb}$, laser induced elemental fractionation, instrumental mass discrimination and time- and depth dependant elemental fractionation of $\mathrm{Pb} / \mathrm{Th}$ and $\mathrm{Pb} / \mathrm{U}$ using an Excel ${ }^{\circledR}$ spreadsheet programme developed by Axel Gerdes (Institut für Geowissenschaften, Johann Wolfgang Goethe-Universität, Frankfurt am Main, Germany). For concordia diagrams (2 sigma error ellipses) and concordia ages (95\% confidence level) Isoplot/Ex 2.49 (Ludwig, 2001) was used, while for frequency and relative probability plots AgeDisplay (Sircombe, 2004) was applied. More details on the analytical protocol and data processing can be found in Frei and Gerdes (2009).

Sample preparation was performed at the Babes-Bolyai University Cluj Napoca (Romania), Department of Geology, while CL images, LA-ICP-MS U-Pb analyses and age calculations were made at the Museum für Mineralogie und Geologie, Sektion Geochronologie, Senckenberg Naturhistorische Sammlungen Dresden (Germany).

\section{$\mathrm{U}-\mathrm{Pb}$ zircon dating results}

Zircons extracted from the sample STA-3 are transparent, either rounded in shape or prismatic with variably rounded edges. 150 grains were ablated and 160 analyses were obtained. From the data set, $112 \mathrm{U}-\mathrm{Pb}$ ages are concordant between 90 and $110 \%$ and are considered for further discussions. Interpreted ages are based on ${ }^{206} \mathrm{~Pb} /{ }^{238} \mathrm{U}$ for grains $<1000 \mathrm{Ma}$ and on ${ }^{206} \mathrm{~Pb} /$ ${ }^{207} \mathrm{~Pb}$ for grains $>1000 \mathrm{Ma}$ in age. 
The zircon age spectrum spans between 81 and $2650 \mathrm{Ma}$ (Appendix 2). Nine grains give Archaen and Paleoproterozoic ages, and eight are Mesoproterozoic (Stenian, 1006-1152 Ma). The most consistent are the Neoproterozoic group with 48 ages (42\%, 554-976 Ma) and the Paleozoic one, with 36 ages (32\%, $432-536 \mathrm{Ma}$ ). Much younger are a Jurassic grain, of $164 \pm 3 \mathrm{Ma}$, and a population of Late Cretaceous age, represented by $10^{206} \mathrm{~Pb}$ / ${ }^{238} \mathrm{U}$ ages between $81 \pm 2$ and $91 \pm 2 \mathrm{Ma}$. The Paleozoic and older ages may be interpreted in terms of provenance, indicating ages of various sources which provided material for Bozeş rocks. Discussing the sources is beyond the purpose of this paper, and therefore these older ages will not be further considered.

\section{$\mathrm{U}-\mathrm{Pb}$ age of sedimentary deposition}

Usually, the youngest detrital zircon age constrains the maximum age of deposition for a sedimentary rock. However, as a single analysis is statistically uncertain, a representative population of grains with analyses of good quality (high concordancy and analytical precision) should constrain the age of the youngest component (Kontinen et al., 2007). Crystallization ages of intruding or crosscutting magmatic rocks, if exist, or any other welldocumented subsequent magmatic event will provide constraints on the minimum age of deposition (Nisbet, 1987).

From the 10 Late Cretaceous ages, the youngest 8 represent a consistent group with a concordia age of $82.87 \pm 0.59$ $(\mathrm{MSWD}=0.0014$ ) (Fig. 3) and a maximum peak at $83 \mathrm{Ma}$ on the probability density distribution (Fig. 4). Excluding from this group the two ages with the largest errors, the obtained concordia age, of $83.13 \pm 0.64$ (MSWD=0.0006) (Fig. 3), is slightly better constrained, but very similar with that of the whole youngest group. Thus, the maximum age of deposition for Bozeş sediments from Stăuinii Valley can be considered as around $83 \mathrm{Ma}$. However, the age of the youngest zircon in the group may be significant, and the maximum age of the deposition could be as young as $81 \pm 2$ Ma. There are no data to precisely constrain the minimum age of sedimentary deposition for the studied deposits.

\section{DISCUSSIONS}

\section{Calcareous nannofossils versus detrital zircons}

The analysis of U-Pb detrital zircon ages indicates that the deposition of the sedimentary rocks on Stăuinii Valley started on around $83 \mathrm{Ma}$ ago, thus in the Early Campanian, but there are no constraints on the duration of the sediment deposition. As

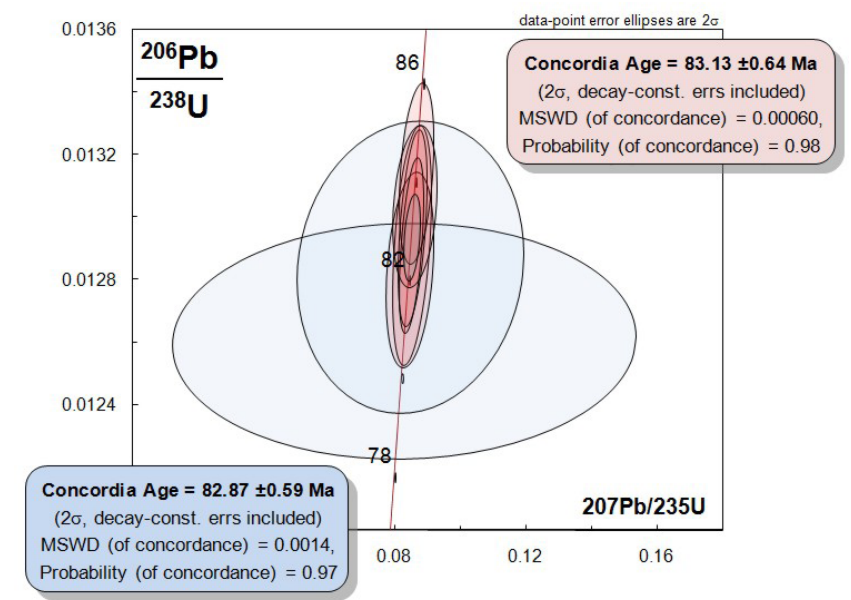

Fig. 3. Concordia diagram and concordia ages for a group of 8 analyses of youngest zircons from sample STA-3 (concordia age in blue - of all group, in red - of group excluding two largest errors).

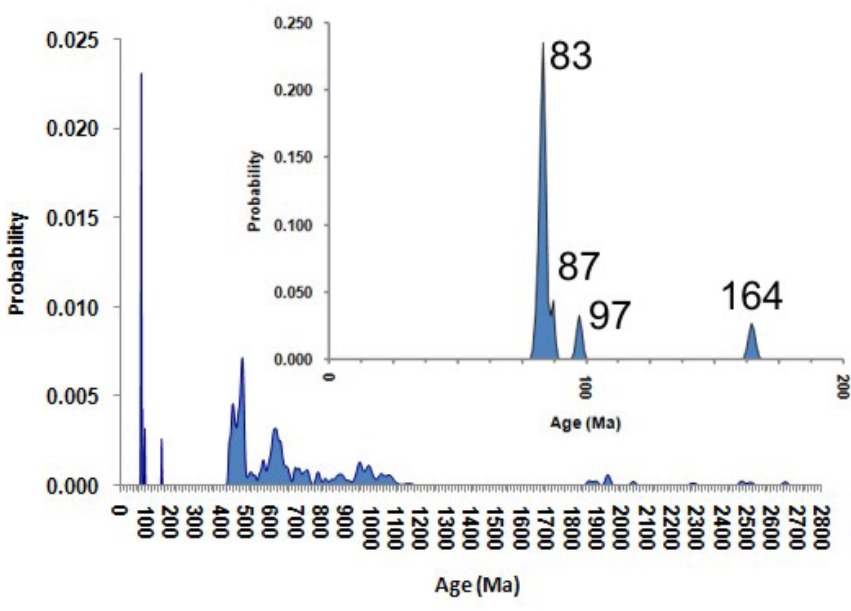

Fig. 4. Probability density distribution plot of detrital zircon grains from sample STA-3. Inset shows enlarged interval of 0-200 Ma, with the corresponding ages of main peaks.

revealed by the calcareous nannofossils investigation, the age of the studied deposits might start from Late Santonian and surely continues until the Late Campanian, below the boundary to the Maastrichtian. The detrital zircon age is more precise concerning the initiation of the sedimentation process, which is established at the lower limit of the Campanian, rather similar with the age of the calcareous nannofossils.

Each method has its own advantages and limitations. Due to the presence of a consistent young zircon population, $\mathrm{U}-\mathrm{Pb}$ geochronology may date more precisely the initiation of sediment deposition, but fails in bracketing this process. On the other hand, calcareous nannofossil studies constrain an age interval for sediments, but the limits are sometimes questionable.

\section{Presence or absence of Maastrichtian}

Sediments of Early Maastrichtian age were mentioned on the Stăuinii Valley by Macovei and Atanasiu (1934), based on ammonite species Pachydiscus neubergicus and P. colligatus, described by Nopcsa (1905, in Macovei and Atanasiu, 1934). Among the recent studies performed on the sediments from Stăuinii Valley, Dimian and Popa-Dimian (1964) collected inoceramids from various stratigraphical levels, without finding $P$. neubergicus. The consistent foraminifera fauna mentioned by Dimian and Popa-Dimian (1964) also precludes the presence of the Early Maastrichtian in Stăuinii area. Few years later, $P$. neubergicus was reported by Tomescu et al. (1969) and used to advocate the presence of the Lower Maastrichtian deposits, although the authors mentioned it as part of a level with typical Late Campanian fauna. The calcareous nannofossil assemblages from Stăuinii Valley section, reported in the present study, argue for a Late Santonian (?) - Late Campanian age for the studied deposits, without any hint for a Maastrichtian age.

While Pachydiscus colligatus is described as a Late Campanian species (e.g. Főzy, 2001), P. neubergicus is usually considered a marker species for Early Maastrichtian, its FO being proposed as a biostratigraphic Campanian/Maastrichtian boundary criterion (e.g. Wagreich et al., 2003). P. neubergicus is now known in European occurrences from the Netherlands (Maastricht area), Denmark, northern Germany, France (Tercis), Spain, Austria (Neuberg), Bulgaria, etc. (Jagt \& Felder, 2003). A correlation study of the local FO of $P$. neubergicus with calcareous nannofossil zone reveals that it has a rather long stratigraphical range, up to late Maastrichtian, 
its local first occurrence being diachronous (Wagreich et al., 2003). Thus, although it is a Maastrichian fossil, it cannot be a reliable marker of the Campanian/Maastrichtian boundary, and additional dating methods are required (Wagreich et al., 2003).

However, it has been shown that the identification of Pachydiscus species is complicated, due to its morphology and to the existence of many names in the literature without precise description (Fözy, 2001). There are cases when the material originally determined as $P$. neubergicus was re-evaluated as different forms of Pachydiscus, e.g. P. precolligatus, P. levyi (Fözy, 2001) or P. perfidus (Machalski, 2012), which are Campanian in age.

In the Stăuinii Valley section, the presence of the Lower Maastrichtian deposits is inferred only from findings of $P$. neubergicus, as mentioned in two older studies (Nopcsa, 1905; Tomescu et al., 1969). Based on foraminifera (Dimian and PopaDimian, 1964) and calcareous nannofossil assemblages (this study), the upper age limit for the Stăuinii section is extended only to the Uppermost Campanian, and we regard the reported Maastrichtian as erroneous.

\section{CONCLUSIONS}

Several methods may be applied to establish the sedimentation age in case of siliciclastic rocks, including direct (fossils) and indirect (radiometric) techniques, each with advantages and limitations. The Stăuinii Valley deposits were the subject of several biostratigraphical studies, the results regarding their age being rather contradictory. Calcareous nannofossils and $\mathrm{U}-\mathrm{Pb}$ detrital zircon were involved in order to compare and correlate the results. Both techniques yielded similar results, indicating probably an Early Campanian age (around $83 \mathrm{Ma}$ ) for the initiation of sediment deposition, but only calcareous nannofossil assemblage succeeded to constrain the ending of sedimentation, as Uppermost Campanian.

The presence of the Lower Maastrichtian deposits on the Stăuinii Valley is questioned as it is sustained only by old findings of Pachydiscus neubergicus. Based on other microfossil assemblages, as foraminifera or calcareous nannofossils, the upper age limit of the studied deposits is considered as Late Campanian, excluding the Lower Maastrichtian deposits from the Stăuinii section.

Acknowledgements. This study was financially supported by CNCSIS-UEFISCSU, project PN II-RU_TE_ 313/2010. Many thanks are due to Mandy Hofmann and Andreas Gartner (Senckenberg Naturhistorische Sammlungen Dresden (Germany) for their help during the zircon dating. We thank two anonymous reviewers for their corrections and suggestions, which helped us improve the manuscript.

\section{REFERENCES}

Avigad, D., Kolodner, K., McWilliams, M., Persing, H. \& Weissbrod, T. 2003, Origin of northern Gondwana Cambrian sandstone revealed by detrital zircon SHRIMP dating. Geology, 31: 227-230. http://dx.doi.org/10.1130/00917613(2003)031<0227:OONGCS $>2.0 . \mathrm{CO} ; 2$

Balintoni, I. 1997, Geotectonics of the metamorphic terrains from Romania. Ed. Carpatica, 176 p (in Romanian).

Balintoni, I. 2003, Towards an improved model of the Laramian Transylvanides. Studia UBB Geologia, Special Issue: 13-20.
Balintoni, I., Balica, C., Cliveţi, M., Li, Q-L., Hann, H.P., Chen, F. \& Schuller, V. 2009, The emplacement age of the Muntele Mare Variscan granite (Apuseni Mountains, Romania). Geologica Carpathica, 60 (6): 495-504. http://dx.doi.org/10.2478/v10096-009-0036-x

Bălc, R., Suciu-Krausz, E. \& Borbei, F. 2007, Biostratigraphy of the Cretaceous deposits in the Western Transylvanides from Ampoi Valley (Southern Apuseni Mountains, Romania). Studia UBB Geologia, 52 (2): 37- 43. http://dx.doi.org/10.5038/1937-8602.52.2.5

Bălc, R., Silye, L. \& Zaharia, L. 2012, Calcareous nannofossils and sedimentary facies in the Upper Cretaceous Bozeş Formation (Southern Apuseni Mountains, Romania). Studia UBB Geologia, 57 (1): 23-32. http://dx.doi.org/10.5038/1937-8602.57.1.3

Bleahu, M., Bordea, S., Lupu, M., Ştefan, A., Patrulius, D. \& Panin, Ş. 1981, The structure of the Apuseni Mountains. Guide to Excursion B3, Carpatho-Balkan Geological Association XII Congress of Geology and Geophysics, 107 p.

Bown, P.R., Young, J.R. 1998, Techniques. In Calcareous nannofossil stratigraphy (Bown, P.R., Ed.): British Micropaleontology Society Series, Chapman \& Hall, London, p. 16-28.

Bown, P.R., Rutledge, D.C., Crux, J.A. \& Gallagher, L.T. 1998, Lower Cretaceous. In Calcareous nannofossil stratigraphy (Bown, P.R., Ed.): British Micropaleontology Society Series, Chapman \& Hall, London, p. 86-131.

Burnett, J.A. 1998, Upper Cretaceous. In Calcareous nannofossil stratigraphy (Bown, P.R., Ed): British Micropaleontology Society Series, Chapman \& Hall, London, p. 132-199.

Csontos, L. 1995, Tertiary tectonic evolution of the IntraCarpathian area. Acta Vulcanologica, 7 (2): 1-13.

Dimian, E., Popa-Dimian, M. 1964, Stratigraphic and sedimentologic data on cretaceous formations between Mureș Valley and Ampoi Valley. Dări de Seamă ale Institului de Geologie, L (1): 107-103 (in Romanian).

Fedo, C.M., Sircombe, K.N. \& Rainbird, R.H. 2003, Detrital zircon analysis of the sedimentary record. In Zircon (Hanchar, J., Hoskin, P.W.O, Eds.): Reviews in Mineralogy and Geochemistry, 53: 277-303.

Frei, D, Gerdes, A. 2009, Precise and accurate in situ U-Pb dating of zircon with high sample throughput by automated LA-SF-ICP-MS. Chemical Geology, 261: 261-270. http://dx.doi.org/10.1016/j.chemgeo.2008.07.025

Főzy, I. 2001, Campanian (Late Cretaceous) cephalopods from Sümeg (Transdanubian Central Range, Hungary). Fragmenta Palaeontologica Hungarica, 19: 25-37.

Ghiţulescu, T.P., Socolescu, M. 1941, Etude geologiques et miniere des Monts Metalliferes. Anuarul Institutului Geologic, XXI: 181- 463.

Ianovici, V., Borcoş, M., Bleahu, M., Patrulius, D., Lupu, M., Dimitrescu, R. \& Savu, H. 1976, Geology of Apuseni Mountains. Ed. Academiei R.S.R., 631 p. (in Romanian).

Jagt, J.W.M., Felder, W.M. 2003, The stratigraphic range of the index ammonite Pachydiscus neubergicus (Hauer, 1858) in the type area of the Maastrichtian Stage. Netherlands Journal of Geosciences / Geologie en Mijnbouw, 82 (3): 261-268. 
Kontinen, A., Käpyaho, A., Huhmab, H., Karhu, J., Matukov, D.I., Larionov, A. \& Sergeev, S.A. 2007, Nurmes paragneisses in eastern Finland, Karelian craton: Provenance tectonic setting and implications for Neoarchaean craton correlation. Precambrian Research, 152: 119-148.

http://dx.doi.org/10.1016/j.precamres.2006.11.001

Ludwig, K.R. 2001, User's Manual for Isoplot/Ex rev. 2.49. Berkeley Geochronology Center, Publication 1a, 56 p.

Lupu, M., Borcos, M., Dimian, M., Lupu, D. \& Dimitrescu, R. 1967, Geological map of Romania, scale 1:200.000, Turda sheet. Geological Institute of Romania.

Maas, R., McCulloch, M.T. 1991, The provenance of Archean clastic metasediments in the Narryer Gneiss Complex, Western Australia: Trace element geochemistry, Nd isotopes, and $\mathrm{U}-\mathrm{Pb}$ ages for detrital zircons. Geochemica et Cosmochimica Acta, 55: 1915-1932. http://dx.doi.org/10.1016/0016-7037(91)90033-2

Macovei, G., Atanasiu, I. 1934, L'evolution geologique de la Roumanie - Cretace. Anuarul Institutului Geologic, XVI: 63-280.

Machalski, M. 2012, Stratigraphically important ammonites from the Campanian-Maastrichtian boundary interval of the Middle Vistula River section, central Poland. Acta Geologica Polonica, 62 (1): 91-116. http://dx.doi.org/10.2478/v10263-012-0004-0

Marincaş, V. 1973, The age of Bozeş Beds. Studia UBB Geologia, 1: 39-46 (in Romanian)

Marincaş, V., Mânecan, D. 1971, Contributions a la stratigraphie du cretace superieur dans la region de Geoagiu. Sargetia, VIII: 21-37

Martini, E. 1971, Standard Tertiary and Quaternary calcareous nannoplankton zonation. In Proceedings of the II Planktonic Conference (Farinacci, A., Ed.), Edizioni Tecnoscienza, Roma: 739-785.

Murray, J. 2006, Ecology and applications of benthic foraminifera. Cambridge University Press, $462 \mathrm{p}$. http://dx.doi.org/10.1017/CBO9780511535529

Nelson, D.R. 2001, An assessment of the determination of depositional ages for Precambrian clastic sedimentary rocks by $\mathrm{U}-\mathrm{Pb}$ dating of detrital zircon. Sedimentary Geology, 141-142: 37-60. http://dx.doi.org/10.1016/S0037-0738(01)00067-7 Nisbet, E.G., 1987. The young Earth: an Introduction to Archaean geology. Allen and Unwin, London, 402 p. http://dx.doi.org/10.1007/978-94-011-6489-4
Okada, H., Bukry, D. 1980, Supplementary modification and introduction of code numbers to the law-latitude coccolith biostratigraphic zonation. Marine Micropaleontology, 5: 321-325. http://dx.doi.org/10.1016/0377-8398(80)90016-X

Perch-Nielsen, K. 1985, Mesozoic calcareous nannofossils. In Plankton stratigraphy (Bolli, H.M., Saunders, J.B., PerchNielsen, K., Eds). Cambridge University Press, 329-426.

Rasmussen, B. 2005, Radiometric dating of sedimentary rocks: the application of diagenetic xenotime geochronology. Earth Sciences Reviews, 68: 197-243.

http://dx.doi.org/10.1016/j.earscirev.2004.05.004

Săndulescu, M. 1984, Geotectonics of Romania. Ed. Tehnica, 336 p (in Romanian).

Sircombe, K.N. 2004, AGEDISPLAY: an EXCEL workbook to evaluate and display univariate geochronological data using binned frequency histograms and probability density distributions. Computer Geosciences, 30: 21-31. http://dx.doi.org/10.1016/j.cageo.2003.09.006

Sissingh, W. 1977, Biostratigraphy of Cretaceous calcareous nannoplankton. Geologie en Mijnbouw, Den Haag, 56: 37-56.

Stacey, J.S., Kramers, J.D. 1975, Approximation of terrestrial lead isotope evolution by a two-stage model. Earth and Planetary Science Letters, 26 (2): 207-221. http://dx.doi.org/10.1016/0012-821X(75)90088-6

Tomescu, C., Panin, Ş., Georgescu, F., Mantea, G. \& Antonescu, E. 1969, Contributions to the Neocretaceous stratigraphy of deposits from Southern Apuseni Mountains. Studii și Cercetări de Geologie, Geofizică, Geografie (Geologie), 14 (1): 239-252 (in Romanian).

Wagreich, M. 1992, Correlation of Late Cretaceous calcareous nannofossil zones with ammonite zones and planktonic Foraminifera: the Austrian Gosau sections. Cretaceous Research, 13: 505-516.

Wagreich, M., Küchler, T. \& Summesberger, H. 2003, Correlation of calcareous nannofossil zones to the local first occurrence of Pachydiscus neubergicus (von Hauer, 1858) (Ammonoidea) in European Upper Cretaceous sections. Netherlands Journal of Geosciences / Geologie en Mijnbouw, 82 (3): 283-288.

http://dx.doi.org/10.1016/0195-6671(92)90014-H

Watkins, D.K., Wise Jr., S.W., Pospichal, J.J. \& Crux, J. 1996, Upper Cretaceous calcareous nannofossil biostratigraphy and paleoceanography of the Southern Ocean, In Microfossils and Oceanic Environments (Moguilevsky, A., Whatley, R., Eds.) Aberystwyth Press, Aberystwyth, U. K., p. 355-381. 


\section{Appendix 1. Taxonomic index}

A full list of all taxa identified in the Stăuinii Valley.

Acutturis scottus (Risatti, 1973) Wind and Wise in Wise and Wind, 1977

Ahmuellerella regularis (Górka, 1957) Reinhardt and Górka, 1967

Ahmuellerella octoradiata (Górka, 1957) Reinhardt, 1966

Amphizygus brooksii Bukry, 1969

Arkhangelksiella confusa Burnett, 1998b

Arkhangelskiella cymbiformis Vekshina, 1959

Arkhangelskiella maastrichtiana Burnett, 1998b

Biscutum constans (Górka, 1957) Black, 1959 in Black and Barnes, 1959

Biscutum dissimilis Wind and Wise in Wise and Wind, 1977

Biscutum magnum Wind and Wise in Wise and Wind, 1977

Braarudosphaera bigelowii (Gran and Braarud, 1935) Deflandre, 1947a

Broinsonia parca (Stradner, 1963) Bukry, 1969, ssp. constricta Hattner et al., 1980

Broinsonia parca (Stradner, 1963) Bukry, 1969, ssp. expansa

Wise and Watkins in Wise, 1983

Broinsonia parca (Stradner, 1963), Bukry 1969, ssp. parca

Broinsonia signata (Noël, 1969) Noël, 1970

Bukryaster hayi (Bukry, 1969) Prins and Sissingh in Sissingh, 1977

Calculites sp. Prins and Sissingh in Sissingh , 1977

Calculites obscurus (Deflandre, 1959) Prins and Sissingh in Sissingh, 1977

Calculites ovalis (Stradner, 1963) Prins and Sissingh in Sissingh, 1977

Ceratolithoides aculeus (Stradner, 1961) Prins and Sissingh in Sissingh 1977

Chiastozygus sp. Gartner, 1968

Chiastozygus amphipons (Bramlette and Martini, 1964) Gartner, 1968

Chiastozygus bifarius Bukry, 1969

Chiastozygus litterarius (Górka, 1957) Manivit, 1971

Corollithion exiguum Stradner, 1961

Corollithion madagaskarensis Perch-Nielsen, 1973

Corollithion signum Stradner, 1963

Cretarhabdus striatus (Stradner, 1963) Black, 1973

Cribrocorona gallica (Stradner 1963) Perch-Nielsen 1973

Cribrosphaerella ehrenbergii (Arkhangelsky, 1912) Deflandre in Pivetteau, 1952

Cyclagelosphaera margerellii Noël, 1965

Cyclagelosphaera reinhardtii (Perch-Nielsen, 1968) Romein, 1977

Cyclagelosphaera rotaclypeata Bukry, 1969

Cylindralithus sp. Bramlette and Martini, 1964

Cylindralithus sculptus Bukry, 1969

Discorhabdus ignotus (Górka, 1957) Perch-Nielsen, 1968

Eiffelithus eximius (Stover, 1966) Perch-Nielsen, 1968

Eiffelithus gorkae Reinhardt, 1965

Eiffelithus parallelus Perch-Nielsen, 1973

Eiffelithus turriseiffelii (Deflandre in Deflandre and Fert, 1954) Reinhardt, 1965

Eprolithus floralis (Stradner, 1962) Stover, 1966

Eprolithus rarus Varol, 1992
Gartnerago segmentatum (Stover, 1966) Thierstein, 1974

Haquis circumradiatus (Stover, 1966) Roth, 1978

Helicolithus anceps (Górka, 1957) Noël, 1970

Helicolithus trabeculatus (Górka, 1957) Verbeek, 1977

Kamptnerius magnificus Deflandre, 1959

Lithastrinus grillii Stradner, 1962

Lithastrinus quadricuspis Farhan, 1987

Lithastrinus septenarius Forchheimer, 1972

Loxolithus armilla (Black in Black and Barnes 1959) Noël, 1965

Lucianorhabdus arcuatus Forchheimer, 1972

Lucianorhabdus cayeuxii Deflandre, 1959

Lucianorhabdus maleformis Reinhardt, 1966

Manivitella pemmatoidea (Deflandre in Manivit, 1965) Thierstein, 1971

Markalius inversus (Deflandre in Deflandre and Fert, 1954) Bramlette and Martini, 1964

Marthasterites furcatus (Deflandre in Deflandre and Fert, 1954) Deflandre, 1959

Marthasterites simplex (Bukry, 1969) Burnett, 1998b

Microrhabdulus belgicus Haye and Towe, 1963

Microrhabdulus decoratus Deflandre, 1959

Microrhabdulus undosus Perch-Nielsen, 1973

Micula concava (Stradner in Martini and Stradner, 1960) Verbeek, 1976b

Micula staurophora (Gardet, 1955) Stradner, 1963

Munarinus sp. Risatti, 1973

Munarinus lesliae Risatti, 1973

Octolithus multiplus (Perch-Nielsen, 1973) Romein, 1979

Okkolithus australis Wind and Wise in Wise and Wind, 1977

Orastrum campanensis (Cepek, 1970) Wind and Wise in Wise and Wind, 1977

Pervilithus varius Crux, 1981

Placozygus fibuliformis (Reinhardt, 1964) Hoffmann, 1970

Prediscosphaera arkhangelskyi (Reinhardt, 1965) PerchNielsen, 1984

Prediscosphaera cretacea (Arkhangelsky, 1912) Gartner, 1968

Prediscosphaera grandis Perch-Nielsen, 1979a

Prediscosphaera ponticula (Bukry, 1969) Perch-Nielsen, 1984

Prediscosphaera spinosa (Bramlette and Martini, 1964) Gartner, 1968

Prediscosphaera stoveri (Perch-Nielsen, 1968) Shafik and Stradner, 1971

Quadrum gartneri Prins and Perch-Nielsen in Manivit el al., 1977 Reinhardtites anthophorus (Deflandre, 1959) Perch-Nielsen, 1968

Reinhardtites levis Prins and Sissingh in Sissingh, 1977

Retecapsa angustiforata Black, 1971a

Retecapsa crenulata (Bramlette and Martini, 1964) Grün in Grün and Allemann, 1975

Rhagodiscus achlyostaurion (Hill, 1976) Doeven, 1983

Rhagodiscus angustus (Stradner, 1963) Reinhardt, 1971

Rhagodiscus reniformis Perch-Nielsen, 1973

Rhagodiscus splendens (Deflandre, 1953) Verbeek, 1977

Russelia bukryi Risatti, 1973 
Russellia laswellii Risatti, 1973

Staurolithites sp. Caratini, 1963

Staurolithites ellipticus (Gartner, 1968) Lambert, 1987

Seribiscutum gaultensis Mutterlose, 1992a

Staurolithites imbricatus (Gartner, 1968) Burnett, 1998b

Staurolithites laffittei Caratini, 1963

Tranolithus minimus (Bukry, 1969) Perch-Nielsen, 1984

Tranolithus orionatus (Reinhardt, 1966a) Reinhardt, 1966b

Uniplanarius gothicus (Deflandre, 1959) Hattner and Wise, 1980

Uniplanarius sissinghii Perch-Nielsen, 1986b

Watznaueria barnesiae (Black, 1959) Perch-Nielsen, 1968

Watznaueria fossacincta (Black, 1971a) Bown in Bown and Cooper, 1989a
Watzanuaeria quadriradiata Bukry, 1969

Watznaueria ovata Bukry, 1969

Zeugrhabdotus sp. Reinhardt, 1965

Zeugrhabdotus bicrescenticus (Stover, 1966) Burnett in Gale et al., 1996

Zeugrhabdotus biperforatus

Zeugrhabdotus diplogrammus (Deflandre in Deflandre and Fert, 1954) Burnett in Gale et al., 1996

Zeugrhabdotus embergeri (Noël, 1958) Perch-Nielsen, 1984 Zeugrhabdotus erectus (Deflandre in Deflandre and Fert, 1954) Reinhardt, 1965

Zeugrhabdotus noeliae Rood et al., 1971

Zeugrhabdotus scutula (Bergen, 1994) Rutledge and Bown, 1996 
Appendix 2. LA-ICPMS U-Pb Detrital zircon age data

U-Pb-Th data of zircon from sample STA-3, $\mathrm{n}=112$ of 160 measured zircon grains (90-110 \% conc.), Late Cretaceous sandstone, Stăuinii Valley, Bozeș Formation, Romania.

\begin{tabular}{|c|c|c|c|c|c|c|c|c|c|c|c|c|c|c|c|}
\hline Name & $\mathrm{TH}^{\mathrm{a}}$ & ${ }^{206} \mathrm{~Pb}^{\mathrm{b}}$ & $2 \sigma$ & ${ }^{207} \mathbf{P b}^{\mathrm{b}}$ & $2 \sigma$ & ${ }^{207} \mathbf{P b}^{b}$ & $2 \sigma$ & & ${ }^{206} \mathrm{~Pb}$ & $\pm 2 \sigma$ & ${ }^{207} \mathrm{~Pb}$ & $\pm 2 \sigma$ & ${ }^{207} \mathrm{~Pb}$ & $\pm 2 \sigma$ & Conc \\
\hline (spot) & $\mathbf{U}$ & ${ }^{238} \mathbf{U}$ & (\%) & ${ }^{235} \mathrm{U}$ & (\%) & ${ }^{206} \mathrm{~Pb}$ & (\%) & $\mathbf{R h o}^{\mathrm{c}}$ & ${ }^{238} \mathrm{U}$ & (Ma) & ${ }^{235} \mathrm{U}$ & (Ma) & ${ }^{206} \mathrm{~Pb}$ & (Ma) & (\%) \\
\hline STA 3-seq1-a52 & 0.71 & 0.01261 & 2.4 & 0.0828 & 69.8 & 0.0476 & 69.8 & 0.04 & 81 & 2 & 81 & 56 & 81 & 1657 & 100 \\
\hline STA 3-seq1-a48 & 0.25 & 0.01284 & 2.0 & 0.0843 & 7.1 & 0.0476 & 6.8 & 0.28 & 82 & 2 & 82 & 6 & 81 & 162 & 101 \\
\hline STA 3-seq1-a49 & 0.27 & 0.01285 & 3.0 & 0.0845 & 33.4 & 0.0477 & 33.3 & 0.09 & 82 & 2 & 82 & 27 & 85 & 789 & 97 \\
\hline STA 3-seq2-B56 & 0.49 & 0.01291 & 1.8 & 0.0849 & 3.4 & 0.0477 & 2.9 & 0.52 & 83 & 1 & 83 & 3 & 83 & 70 & 100 \\
\hline STA 3-seq3-C54 & 0.30 & 0.01291 & 2.4 & 0.0849 & 5.8 & 0.0477 & 5.3 & 0.42 & 83 & 2 & 83 & 5 & 84 & 126 & 98 \\
\hline STA 3-seq2-B02 & 0.24 & 0.01297 & 2.0 & 0.0852 & 4.2 & 0.0477 & 3.7 & 0.47 & 83 & 2 & 83 & 3 & 83 & 88 & 100 \\
\hline STA 3-seq2-B55 & 0.42 & 0.01304 & 1.6 & 0.0859 & 6.5 & 0.0478 & 6.3 & 0.25 & 84 & 1 & 84 & 5 & 87 & 150 & 96 \\
\hline STA 3-seq2-B04 & 0.26 & 0.01314 & 1.8 & 0.0865 & 5.1 & 0.0477 & 4.7 & 0.36 & 84 & 2 & 84 & 4 & 85 & 112 & 99 \\
\hline STA 3-seq2-B19 & 0.74 & 0.01355 & 1.8 & 0.0893 & 6.4 & 0.0478 & 6.2 & 0.28 & 87 & 2 & 87 & 5 & 89 & 146 & 97 \\
\hline STA 3-seq2-B18 & 0.42 & 0.01517 & 2.3 & 0.1004 & 6.4 & 0.0480 & 6.0 & 0.35 & 97 & 2 & 97 & 6 & 99 & 143 & 98 \\
\hline STA 3-seq2-B52 & 0.45 & 0.02579 & 1.6 & 0.1754 & 3.9 & 0.0493 & 3.5 & 0.42 & 164 & 3 & 164 & 6 & 164 & 82 & 100 \\
\hline STA 3-seq2-B25 & 0.26 & 0.06937 & 1.5 & 0.5403 & 1.8 & 0.0565 & 1.0 & 0.82 & 432 & 6 & 439 & 7 & 472 & 23 & 92 \\
\hline STA 3-seq1-a27 & 0.40 & 0.07011 & 2.0 & 0.5371 & 2.5 & 0.0556 & 1.4 & 0.83 & 437 & 9 & 437 & 9 & 435 & 30 & 100 \\
\hline STA 3-seq1-a38 & 0.06 & 0.07043 & 2.4 & 0.5400 & 3.1 & 0.0556 & 1.9 & 0.78 & 439 & 10 & 438 & 11 & 437 & 43 & 101 \\
\hline STA 3-seq3-C32 & 0.09 & 0.07059 & 3.4 & 0.5434 & 4.1 & 0.0558 & 2.3 & 0.83 & 440 & 14 & 441 & 15 & 446 & 51 & 99 \\
\hline STA 3-seq1-a 44 & 0.44 & 0.07127 & 2.0 & 0.5474 & 2.4 & 0.0557 & 1.4 & 0.82 & 444 & 8 & 443 & 9 & 441 & 31 & 101 \\
\hline STA 3-seq1-a30 & 0.06 & 0.07180 & 2.1 & 0.5561 & 3.1 & 0.0562 & 2.3 & 0.68 & 447 & 9 & 449 & 11 & 459 & 50 & 97 \\
\hline STA 3-seq2-B30 & 0.29 & 0.07182 & 1.9 & 0.5560 & 3.2 & 0.0561 & 2.5 & 0.61 & 447 & 8 & 449 & 12 & 458 & 56 & 98 \\
\hline STA 3-seq3-C16 & 0.32 & 0.07233 & 2.4 & 0.5591 & 2.7 & 0.0561 & 1.2 & 0.89 & 450 & 11 & 451 & 10 & 455 & 28 & 99 \\
\hline STA 3-seq1-a25 & 0.21 & 0.07247 & 2.2 & 0.5586 & 3.4 & 0.0559 & 2.5 & 0.66 & 451 & 10 & 451 & 12 & 448 & 56 & 101 \\
\hline STA 3-seq1-a26 & 0.50 & 0.07252 & 2.3 & 0.5581 & 2.7 & 0.0558 & 1.4 & 0.86 & 451 & 10 & 450 & 10 & 445 & 31 & 101 \\
\hline STA 3-seq3-C26 & 0.10 & 0.07354 & 2.4 & 0.5694 & 3.1 & 0.0562 & 2.0 & 0.76 & 457 & 10 & 458 & 11 & 459 & 44 & 100 \\
\hline STA 3-seq3-C46 & 0.08 & 0.07367 & 2.3 & 0.5695 & 2.9 & 0.0561 & 1.7 & 0.80 & 458 & 10 & 458 & 11 & 455 & 38 & 101 \\
\hline STA 3-seq3-C17 & 0.11 & 0.07436 & 2.6 & 0.5756 & 3.6 & 0.0561 & 2.5 & 0.72 & 462 & 12 & 462 & 14 & 458 & 55 & 101 \\
\hline STA 3-seq1-a60 & 0.11 & 0.07451 & 3.2 & 0.5877 & 4.9 & 0.0572 & 3.7 & 0.65 & 463 & 14 & 469 & 19 & 499 & 82 & 93 \\
\hline STA 3-seq3-C60 & 0.27 & 0.07478 & 3.2 & 0.5864 & 3.6 & 0.0569 & 1.7 & 0.88 & 465 & 14 & 469 & 14 & 486 & 38 & 96 \\
\hline STA 3-seq2-B12 & 0.21 & 0.07553 & 2.0 & 0.5890 & 3.1 & 0.0566 & 2.3 & 0.66 & 469 & 9 & 470 & 12 & 475 & 51 & 99 \\
\hline STA 3-seq3-C47 & 0.09 & 0.07589 & 2.4 & 0.5926 & 3.3 & 0.0566 & 2.2 & 0.73 & 472 & 11 & 473 & 12 & 477 & 49 & 99 \\
\hline STA 3-seq3-C52 & 0.34 & 0.07594 & 2.2 & 0.5934 & 3.1 & 0.0567 & 2.1 & 0.73 & 472 & 10 & 473 & 12 & 479 & 47 & 99 \\
\hline STA 3-seq1-a57 & 0.40 & 0.07609 & 2.2 & 0.5962 & 3.4 & 0.0568 & 2.6 & 0.64 & 473 & 10 & 475 & 13 & 485 & 57 & 98 \\
\hline STA 3-seq2-B44 & 0.12 & 0.07715 & 1.7 & 0.6107 & 2.7 & 0.0574 & 2.1 & 0.63 & 479 & 8 & 484 & 11 & 507 & 47 & 94 \\
\hline STA 3-seq2-B21 & 0.11 & 0.07733 & 1.9 & 0.6185 & 3.6 & 0.0580 & 3.1 & 0.52 & 480 & 9 & 489 & 14 & 530 & 67 & 91 \\
\hline STA 3-seq1-a18 & 0.08 & 0.07737 & 2.7 & 0.6023 & 3.5 & 0.0565 & 2.2 & 0.77 & 480 & 12 & 479 & 13 & 470 & 49 & 102 \\
\hline STA 3-seq3-C02 & 0.05 & 0.07740 & 2.7 & 0.6081 & 3.9 & 0.0570 & 2.7 & 0.71 & 481 & 13 & 482 & 15 & 491 & 60 & 98 \\
\hline STA 3-seq3-C03 & 0.14 & 0.07815 & 2.5 & 0.6156 & 3.2 & 0.0571 & 2.1 & 0.77 & 485 & 12 & 487 & 13 & 497 & 45 & 98 \\
\hline STA 3-seq2-B40 & 0.12 & 0.07817 & 2.4 & 0.6096 & 2.9 & 0.0566 & 1.7 & 0.81 & 485 & 11 & 483 & 11 & 474 & 38 & 102 \\
\hline STA 3-seq2-B36 & 0.06 & 0.07818 & 2.1 & 0.6143 & 3.3 & 0.0570 & 2.6 & 0.63 & 485 & 10 & 486 & 13 & 491 & 57 & 99 \\
\hline STA 3-seq2-B26 & 0.26 & 0.07826 & 1.6 & 0.6135 & 2.6 & 0.0569 & 2.1 & 0.61 & 486 & 7 & 486 & 10 & 486 & 46 & 100 \\
\hline STA 3-seq2-B47 & 0.15 & 0.07840 & 2.2 & 0.6158 & 3.5 & 0.0570 & 2.7 & 0.63 & 487 & 10 & 487 & 14 & 490 & 60 & 99 \\
\hline STA 3-seq1-a08 & 0.18 & 0.07869 & 2.4 & 0.6263 & 2.9 & 0.0577 & 1.6 & 0.83 & 488 & 11 & 494 & 12 & 519 & 36 & 94 \\
\hline STA 3-seq1-a24 & 0.11 & 0.07890 & 2.1 & 0.6206 & 3.1 & 0.0570 & 2.3 & 0.68 & 490 & 10 & 490 & 12 & 493 & 50 & 99 \\
\hline STA 3-seq2-B38 & 0.09 & 0.07905 & 1.9 & 0.6219 & 3.0 & 0.0571 & 2.3 & 0.63 & 490 & 9 & 491 & 12 & 494 & 51 & 99 \\
\hline STA 3-seq1-a35 & 0.44 & 0.07912 & 1.9 & 0.6302 & 3.4 & 0.0578 & 2.9 & 0.55 & 491 & 9 & 496 & 13 & 521 & 63 & 94 \\
\hline STA 3-seq2-B22 & 0.15 & 0.07987 & 2.6 & 0.6306 & 3.6 & 0.0573 & 2.4 & 0.73 & 495 & 12 & 496 & 14 & 502 & 53 & 99 \\
\hline STA 3-seq3-C34 & 0.26 & 0.08265 & 2.7 & 0.6573 & 3.6 & 0.0577 & 2.3 & 0.76 & 512 & 13 & 513 & 14 & 518 & 51 & 99 \\
\hline STA 3-seq3-C37 & 0.27 & 0.08441 & 2.3 & 0.6829 & 2.9 & 0.0587 & 1.8 & 0.79 & 522 & 11 & 529 & 12 & 555 & 38 & 94 \\
\hline STA 3-seq1-a33 & 0.64 & 0.08669 & 2.2 & 0.6948 & 3.2 & 0.0581 & 2.3 & 0.70 & 536 & 12 & 536 & 14 & 535 & 51 & 100 \\
\hline STA 3-seq1-a21 & 0.28 & 0.08975 & 2.2 & 0.7464 & 2.7 & 0.0603 & 1.7 & 0.79 & 554 & 11 & 566 & 12 & 615 & 36 & 90 \\
\hline STA 3-seq3-C48 & 0.54 & 0.09207 & 2.2 & 0.7607 & 2.6 & 0.0599 & 1.4 & 0.84 & 568 & 12 & 574 & 12 & 601 & 31 & 95 \\
\hline STA 3-seq3-C06 & 0.23 & 0.09259 & 2.9 & 0.7557 & 3.5 & 0.0592 & 1.9 & 0.84 & 571 & 16 & 572 & 15 & 574 & 42 & 99 \\
\hline STA 3-seq1-a23 & 0.52 & 0.09278 & 2.6 & 0.7630 & 3.2 & 0.0596 & 1.8 & 0.82 & 572 & 14 & 576 & 14 & 591 & 39 & 97 \\
\hline STA 3-seq3-C14 & 0.26 & 0.09566 & 2.5 & 0.8064 & 3.0 & 0.0611 & 1.6 & 0.84 & 589 & 14 & 600 & 13 & 644 & 34 & 91 \\
\hline
\end{tabular}




\begin{tabular}{|c|c|c|c|c|c|c|c|c|c|c|c|c|c|c|c|}
\hline $\begin{array}{l}\text { Name } \\
\text { (spot) }\end{array}$ & $-{ }_{\mathrm{U}}^{\mathrm{TH}_{-}^{\mathrm{a}}}$ & $\begin{array}{c}{ }^{206} \mathrm{~Pb}^{\mathrm{b}} \\
{ }^{238} \mathrm{U}\end{array}$ & $\begin{array}{l}2 \sigma \\
(\%)\end{array}$ & $\begin{array}{l}-{ }^{207} \mathbf{P b}^{\mathbf{b}} \\
-{ }^{235} \mathbf{U}\end{array}$ & $\begin{array}{l}2 \sigma \\
(\%)\end{array}$ & $\begin{array}{r}-{ }^{207} \mathbf{P b}^{\mathrm{b}} \\
{ }^{206} \mathrm{~Pb}\end{array}$ & $\begin{array}{l}2 \sigma \\
(\%)\end{array}$ & $\mathrm{Rho}^{\mathrm{c}}$ & $-{ }^{206} \mathrm{~Pb}$ & $\begin{array}{l} \pm 2 \sigma \\
\text { (Ма) }\end{array}$ & $\begin{array}{r}{ }^{207} \mathrm{~Pb} \\
{ }^{235} \mathrm{U}\end{array}$ & $\begin{array}{l} \pm 2 \sigma \\
\text { (Ma) }\end{array}$ & $\begin{array}{r}-{ }^{207} \mathrm{~Pb} \\
{ }^{206} \mathrm{~Pb}\end{array}$ & $\begin{array}{l} \pm 2 \sigma \\
\text { (Ma) }\end{array}$ & $\begin{array}{l}\text { Conc } \\
(\%)\end{array}$ \\
\hline STA 3-seq3-C15 & 0.20 & 0.09617 & 2.3 & 0.8010 & 2.9 & 0.0604 & 1.9 & 0.77 & 592 & 13 & 597 & 13 & 618 & 40 & 96 \\
\hline STA 3-seq2-B54 & 0.75 & 0.09744 & 2.1 & 0.8059 & 3.0 & 0.0600 & 2.2 & 0.68 & 599 & 12 & 600 & 14 & 603 & 48 & 99 \\
\hline STA 3-seq2-B32 & 0.36 & 0.09833 & 2.0 & 0.8281 & 2.6 & 0.0611 & 1.7 & 0.75 & 605 & 11 & 613 & 12 & 642 & 37 & 94 \\
\hline STA 3-seq2-B23 & 0.20 & 0.09885 & 2.3 & 0.8191 & 2.9 & 0.0601 & 1.8 & 0.78 & 608 & 13 & 608 & 13 & 607 & 40 & 100 \\
\hline STA 3-seq1-a06 & 0.40 & 0.09945 & 1.7 & 0.8339 & 2.2 & 0.0608 & 1.4 & 0.77 & 611 & 10 & 616 & 10 & 633 & 31 & 97 \\
\hline STA 3-seq3-C44 & 0.97 & 0.09975 & 2.5 & 0.8377 & 3.2 & 0.0609 & 2.0 & 0.79 & 613 & 15 & 618 & 15 & 636 & 43 & 96 \\
\hline STA 3-seq1-a37 & 0.81 & 0.10006 & 2.1 & 0.8440 & 2.8 & 0.0612 & 1.8 & 0.76 & 615 & 12 & 621 & 13 & 645 & 39 & 95 \\
\hline STA 3-seq3-C07 & 0.36 & 0.10033 & 2.7 & 0.8390 & 3.0 & 0.0606 & 1.3 & 0.89 & 616 & 16 & 619 & 14 & 627 & 29 & 98 \\
\hline STA 3-seq2-B42 & 0.89 & 0.10099 & 1.7 & 0.8316 & 2.7 & 0.0597 & 2.2 & 0.61 & 620 & 10 & 614 & 13 & 594 & 47 & 104 \\
\hline STA 3-seq2-B60 & 0.46 & 0.10163 & 1.8 & 0.8479 & 2.6 & 0.0605 & 1.9 & 0.68 & 624 & 11 & 624 & 12 & 622 & 42 & 100 \\
\hline STA 3-seq1-a56 & 0.70 & 0.10163 & 2.1 & 0.8412 & 2.9 & 0.0600 & 2.0 & 0.74 & 624 & 13 & 620 & 14 & 605 & 43 & 103 \\
\hline STA 3-seq1-a20 & 0.53 & 0.10253 & 1.7 & 0.8589 & 2.1 & 0.0608 & 1.3 & 0.79 & 629 & 10 & 630 & 10 & 631 & 28 & 100 \\
\hline STA 3-seq3-C13 & 0.20 & 0.10363 & 2.3 & 0.8765 & 2.9 & 0.0613 & 1.7 & 0.80 & 636 & 14 & 639 & 14 & 651 & 37 & 98 \\
\hline STA 3-seq2-B41 & 0.64 & 0.10383 & 1.9 & 0.8632 & 2.7 & 0.0603 & 2.0 & 0.69 & 637 & 11 & 632 & 13 & 614 & 43 & 104 \\
\hline STA 3-seq2-B27 & 1.12 & 0.10428 & 1.9 & 0.8841 & 2.6 & 0.0615 & 1.9 & 0.70 & 639 & 11 & 643 & 13 & 657 & 40 & 97 \\
\hline STA 3-seq2-B28 & 2.17 & 0.10453 & 2.0 & 0.8777 & 3.6 & 0.0609 & 3.0 & 0.56 & 641 & 12 & 640 & 17 & 636 & 65 & 101 \\
\hline STA 3-seq1-a 01 & 0.40 & 0.10598 & 1.8 & 0.8957 & 2.6 & 0.0613 & 1.9 & 0.69 & 649 & 11 & 649 & 12 & 650 & 40 & 100 \\
\hline STA 3-seq2-B34 & 0.34 & 0.10790 & 2.2 & 0.9128 & 2.8 & 0.0614 & 1.7 & 0.79 & 661 & 14 & 659 & 14 & 652 & 37 & 101 \\
\hline STA 3-seq3-C08 & 0.43 & 0.10807 & 2.5 & 0.9134 & 3.1 & 0.0613 & 1.8 & 0.81 & 662 & 16 & 659 & 15 & 650 & 39 & 102 \\
\hline STA 3-seq1-a36 & 0.09 & 0.11000 & 2.2 & 0.9334 & 2.9 & 0.0615 & 1.9 & 0.76 & 673 & 14 & 669 & 14 & 658 & 40 & 102 \\
\hline STA 3-seq2-B13 & 0.31 & 0.11400 & 1.7 & 0.9791 & 2.7 & 0.0623 & 2.1 & 0.61 & 696 & 11 & 693 & 14 & 684 & 46 & 102 \\
\hline STA 3-seq3-C51 & 0.19 & 0.11463 & 2.7 & 1.0199 & 3.4 & 0.0645 & 2.0 & 0.81 & 700 & 18 & 714 & 17 & 759 & 42 & 92 \\
\hline STA 3-seq1-a45 & 0.25 & 0.11682 & 1.9 & 1.0084 & 3.4 & 0.0626 & 2.8 & 0.56 & 712 & 13 & 708 & 17 & 695 & 60 & 102 \\
\hline STA 3-seq3-C35 & 0.46 & 0.11777 & 2.8 & 1.0194 & 4.9 & 0.0628 & 4.0 & 0.57 & 718 & 19 & 714 & 25 & 701 & 85 & 102 \\
\hline STA 3-seq2-B50 & 0.13 & 0.12017 & 1.9 & 1.0810 & 2.7 & 0.0652 & 2.0 & 0.68 & 732 & 13 & 744 & 15 & 782 & 42 & 94 \\
\hline STA 3-seq1-a15 & 0.38 & 0.12232 & 1.8 & 1.1001 & 4.4 & 0.0652 & 4.0 & 0.42 & 744 & 13 & 753 & 24 & 782 & 83 & 95 \\
\hline STA 3-seq1-a17 & 1.76 & 0.12344 & 2.4 & 1.1097 & 4.2 & 0.0652 & 3.4 & 0.57 & 750 & 17 & 758 & 23 & 781 & 72 & 96 \\
\hline STA 3-seq3-C29 & 0.30 & 0.12976 & 2.3 & 1.1676 & 3.1 & 0.0653 & 2.1 & 0.75 & 787 & 17 & 786 & 17 & 783 & 43 & 100 \\
\hline STA 3-seq3-C41 & 0.36 & 0.13017 & 2.3 & 1.1778 & 4.0 & 0.0656 & 3.2 & 0.57 & 789 & 17 & 790 & 22 & 794 & 68 & 99 \\
\hline STA 3-seq1-a46 & 0.41 & 0.13506 & 2.1 & 1.2543 & 2.6 & 0.0674 & 1.6 & 0.79 & 817 & 16 & 825 & 15 & 849 & 34 & 96 \\
\hline STA 3-seq3-C09 & 0.52 & 0.13949 & 2.3 & 1.3133 & 5.0 & 0.0683 & 4.4 & 0.47 & 842 & 18 & 852 & 29 & 877 & 91 & 96 \\
\hline STA 3-seq3-C24 & 0.43 & 0.14348 & 2.3 & 1.3361 & 3.5 & 0.0675 & 2.7 & 0.64 & 864 & 18 & 862 & 21 & 854 & 56 & 101 \\
\hline STA 3-seq3-C40 & 0.56 & 0.14536 & 2.8 & 1.3569 & 3.2 & 0.0677 & 1.6 & 0.87 & 875 & 23 & 871 & 19 & 859 & 32 & 102 \\
\hline STA 3-seq3-C59 & 0.49 & 0.14728 & 2.1 & 1.3817 & 2.7 & 0.0680 & 1.6 & 0.79 & 886 & 18 & 881 & 16 & 870 & 33 & 102 \\
\hline STA 3-seq1-a51 & 0.06 & 0.15141 & 2.5 & 1.4448 & 2.8 & 0.0692 & 1.3 & 0.89 & 909 & 21 & 908 & 17 & 905 & 26 & 100 \\
\hline STA 3-seq3-C43 & 0.42 & 0.15671 & 2.3 & 1.5479 & 2.8 & 0.0716 & 1.7 & 0.80 & 938 & 20 & 950 & 18 & 976 & 34 & 96 \\
\hline STA 3-seq2-B11 & 0.52 & 0.15925 & 1.9 & 1.5791 & 2.8 & 0.0719 & 2.1 & 0.68 & 953 & 17 & 962 & 18 & 984 & 42 & 97 \\
\hline STA 3-seq1-a31 & 0.39 & 0.15939 & 2.4 & 1.5873 & 3.4 & 0.0722 & 2.4 & 0.70 & 953 & 21 & 965 & 21 & 992 & 49 & 96 \\
\hline STA 3-seq3-C22 & 0.52 & 0.16009 & 2.2 & 1.6184 & 2.5 & 0.0733 & 1.2 & 0.88 & 957 & 19 & 977 & 16 & 1023 & 24 & 94 \\
\hline STA 3-seq3-C39 & 0.56 & 0.16391 & 2.6 & 1.6407 & 3.2 & 0.0726 & 1.8 & 0.82 & 978 & 24 & 986 & 20 & 1003 & 37 & 98 \\
\hline STA 3-seq2-B08 & 0.64 & 0.16582 & 2.1 & 1.6571 & 2.7 & 0.0725 & 1.7 & 0.78 & 989 & 19 & 992 & 17 & 999 & 34 & 99 \\
\hline STA 3-seq1-a10 & 0.29 & 0.16716 & 2.4 & 1.6869 & 2.8 & 0.0732 & 1.5 & 0.84 & 996 & 22 & 1004 & 18 & 1019 & 31 & 98 \\
\hline STA 3-seq3-C55 & 0.74 & 0.17080 & 2.1 & 1.6870 & 3.0 & 0.0716 & 2.1 & 0.72 & 1017 & 20 & 1004 & 19 & 976 & 43 & 104 \\
\hline STA 3-seq1-a58 & 0.28 & 0.17441 & 2.5 & 1.7485 & 4.3 & 0.0727 & 3.4 & 0.59 & 1036 & 24 & 1027 & 28 & 1006 & 70 & 103 \\
\hline STA 3-seq1-a19 & 0.61 & 0.17153 & 1.9 & 1.7197 & 2.6 & 0.0727 & 1.9 & 0.71 & 1021 & 18 & 1016 & 17 & 1006 & 38 & 101 \\
\hline STA 3-seq1-a16 & 0.19 & 0.17560 & 1.8 & 1.7892 & 2.0 & 0.0739 & 0.9 & 0.88 & 1043 & 17 & 1042 & 13 & 1039 & 19 & 100 \\
\hline STA 3-seq2-B43 & 0.99 & 0.17707 & 3.0 & 1.8139 & 3.5 & 0.0743 & 1.9 & 0.84 & 1051 & 29 & 1050 & 23 & 1049 & 38 & 100 \\
\hline STA 3-seq1-a05 & 0.74 & 0.17152 & 2.7 & 1.7752 & 3.4 & 0.0751 & 2.1 & 0.79 & 1021 & 26 & 1036 & 23 & 1070 & 42 & 95 \\
\hline STA 3-seq3-C31 & 0.32 & 0.18175 & 2.4 & 1.8845 & 2.7 & 0.0752 & 1.3 & 0.88 & 1077 & 24 & 1076 & 18 & 1074 & 26 & 100 \\
\hline STA 3-seq2-B06 & 0.57 & 0.18362 & 2.0 & 1.9183 & 3.3 & 0.0758 & 2.7 & 0.59 & 1087 & 20 & 1087 & 23 & 1089 & 54 & 100 \\
\hline STA 3-seq1-a07 & 0.34 & 0.18812 & 2.6 & 2.0289 & 3.3 & 0.0782 & 2.1 & 0.77 & 1111 & 26 & 1125 & 23 & 1152 & 42 & 96 \\
\hline STA 3-seq3-C19 & 0.38 & 0.34109 & 2.2 & 5.3726 & 2.5 & 0.1142 & 1.2 & 0.87 & 1892 & 37 & 1881 & 22 & 1868 & 22 & 101 \\
\hline STA 3-seq1-a13 & 0.33 & 0.33732 & 1.9 & 5.3996 & 2.3 & 0.1161 & 1.3 & 0.82 & 1874 & 30 & 1885 & 20 & 1897 & 23 & 99 \\
\hline STA 3-seq2-B20 & 0.38 & 0.34240 & 2.1 & 5.6212 & 2.4 & 0.1191 & 1.0 & 0.91 & 1898 & 35 & 1919 & 21 & 1942 & 17 & 98 \\
\hline STA 3-seq1-a29 & 0.62 & 0.34357 & 2.4 & 5.6530 & 2.8 & 0.1193 & 1.5 & 0.85 & 1904 & 40 & 1924 & 25 & 1946 & 26 & 98 \\
\hline STA 3-seq3-C01 & 0.26 & 0.36577 & 2.5 & 6.3621 & 2.9 & 0.1262 & 1.4 & 0.88 & 2009 & 44 & 2027 & 26 & 2045 & 25 & 98 \\
\hline
\end{tabular}




\begin{tabular}{|c|c|c|c|c|c|c|c|c|c|c|c|c|c|c|c|}
\hline Name & $\mathrm{TH}^{\mathrm{a}}$ & ${ }^{206} \mathrm{~Pb}^{\mathrm{b}}$ & $2 \sigma$ & ${ }^{207} \mathbf{P b}^{\mathrm{b}}$ & $2 \sigma$ & ${ }^{207} \mathbf{P b}^{\mathrm{b}}$ & $2 \sigma$ & & ${ }^{206} \mathrm{~Pb}$ & $\pm 2 \sigma$ & ${ }^{207} \mathrm{~Pb}$ & $\pm 2 \sigma$ & ${ }^{207} \mathrm{~Pb}$ & $\pm 2 \sigma$ & Conc \\
\hline (spot) & $\mathbf{U}$ & ${ }^{238} \mathrm{U}$ & (\%) & ${ }^{235} \mathrm{U}$ & (\%) & ${ }^{206} \mathrm{~Pb}$ & (\%) & $\mathbf{R h o}^{\mathrm{c}}$ & ${ }^{238} \mathrm{U}$ & (Ma) & ${ }^{235} \mathrm{U}$ & (Ma) & ${ }^{206} \mathrm{~Pb}$ & (Ma) & (\%) \\
\hline STA 3-seq2-B53 & .067 & 0.41207 & 2.1 & 8.2172 & 2.9 & 0.1446 & 2.0 & 0.72 & 2224 & 39 & 2255 & 26 & 2283 & 35 & 97 \\
\hline STA 3-seq3-C11 & 0.17 & 0.48162 & 2.7 & 10.7532 & 3.0 & 0.1619 & 1.4 & 0.89 & 2534 & 57 & 2502 & 29 & 2476 & 23 & 102 \\
\hline STA 3-seq2-B03 & 0.73 & 0.47820 & 1.7 & 10.9146 & 2.4 & 0.1655 & 1.7 & 0.71 & 2519 & 37 & 2516 & 23 & 2513 & 29 & 100 \\
\hline STA 3-seq3-C25 & 1.06 & 0.52094 & 2.3 & 12.9103 & 2.8 & 0.1797 & 1.6 & 0.83 & 2703 & 51 & 2673 & 27 & 2650 & 26 & 102 \\
\hline
\end{tabular}

${ }^{\mathrm{a}} \mathrm{U}$ and $\mathrm{Pb}$ content and $\mathrm{Th} / \mathrm{U}$ ratio were calculated relative to GJ-1 and are accurate to approximately $10 \%$.

${ }^{b}$ corrected for background, mass bias, laser induced $\mathrm{U}-\mathrm{Pb}$ fractionation and common $\mathrm{Pb}$ (if detectable, see analytical method) using Stacey \& Kramers (1975)

'Rho is the error correlation defined as err206Pb/238U/err207Pb/235U. 